\title{
Correction to: Molecular characterization of NDM-1-producing Pseudomonas aeruginosa isolates from hospitalized patients in Iran
}

Mojtaba Shahin ${ }^{1,2}$ and Ali Ahmadi ${ }^{*}$

\section{Correction to: Ann Clin Microbiol Antimicrob (2021) 20:76 https://doi.org/10.1186/s12941-021-00482-3}

Following publication of the original article [1], the affiliation details for the corresponding author "Ali Ahmadi" were incorrectly given as "Department of Medical Laboratory Sciences, Faculty of Medical Sciences, Arak Branch, Islamic Azad University, Arak, Iran" but should have been "Molecular Biology Research Center, Systems Biology and Poisonings Institute, Baqiyatallah University of Medical Sciences, Tehran, Iran". These have been corrected with this erratum.

The original article has been corrected.

\section{Author details}

'Molecular Biology Research Center, Systems Biology and Poisonings Institute, Baqiyatallah University of Medical Sciences, Tehran, Iran. ${ }^{2}$ Department of Medical Laboratory Sciences, Faculty of Medical Sciences, Arak Branch, Islamic Azad University, Arak, Iran.

Published online: 11 December 2021
Reference

1. Shahin M, Ahmadi A. Molecular characterization of NDM-1-producing Pseudomonas aeruginosa isolates from hospitalized patients in Iran. Ann Clin Microbiol Antimicrob. 2021;20:76.

\section{Publisher's Note}

Springer Nature remains neutral with regard to jurisdictional claims in published maps and institutional affiliations. permits use, sharing, adaptation, distribution and reproduction in any medium or format, as long as you give appropriate credit to the original author(s) and the source, provide a link to the Creative Commons licence, and indicate if changes were made. The images or other third party material in this article are included in the article's Creative Commons licence, unless indicated otherwise in a credit line to the material. If material is not included in the article's Creative Commons licence and your intended use is not permitted by statutory regulation or exceeds the permitted use, you will need to obtain permission directly from the copyright holder. To view a copy of this licence, visit http://creativecommons.org/licenses/by/4.0/. The Creative Commons Public Domain Dedication waiver (http://creativeco mmons.org/publicdomain/zero/1.0/) applies to the data made available in this article, unless otherwise stated in a credit line to the data. 